\title{
PELAKSANAAN PRINSIP KERJA SAMA DALAM PERCAKAPAN GURU DAN SISWA SERTA DAMPAKNYA TERHADAP PEMBELAJARAN BAHASA INDONESIA DI KELAS XI SMAN I KEDIRI
}

\author{
Ni Wayan Eminda Sari \\ Program Studi Pendidikan Bahasa Indonesia \\ Fakultas Keguruan dan Ilmu Pendidikan \\ Universitas Mahasaraswati Denpasar
}

\begin{abstract}
This study aimed at gathering illustrations and explanation about (1) learning context as a field of the implementation for cooperative principle in a classroom learning, (2) the cooperative principle conducted by the teacher, (3) the implementation of cooperative principle conducted by the students, (4) the effects of cooperative principle which is conducted by teacher and students upon Indonesian learning in the class XI SMAN 1 Kediri. In order to achieve these goals, this study uses the descriptivequalitative design. The subject of the study is the students and Indonesian teacher at the class XI SMAN 1 Kediri. The data gathering is conducted by the methods of recording, observation, and interview. The data gained then was analyzed qualitatively descriptive that covers four phases, namely data gathering, data reduction, data presentation, verification, and conclusion making. The results of this study shows that learning context as the field of cooperative principle implementation in the classroom, dominantly appears in formal situation, and appears also in semi-formal and nonformal situation. The cooperative principle conducted by the teacher is marked by teacher's speech that obeyed the maxim of quantity, maxim of quality, maxim of relevance, and maxim of manner. The implementation of cooperative principle conducted by the students is marked by teacher's speech that obeyed the maxim of quantity, maxim of quality, maxim of relevance, and maxim of manner. The effects that appear due to the implementation of cooperative principle upon Indonesia is that the situation of the learning in the classroom become conducive and comfortable, students' activity is developed, the learning runs well without any disturbances, and the goals of the teaching can be achieved effectively. Based on the result of this study, the readers expected to realize that in the use of speech, cooperative principle needs to be considered so that the conversation can be more effective and efficient.
\end{abstract}

Key words : cooperative principle, maxim of quantity, maxim of quality, maxim of relevance, maxim of manner, conversation between teacher and students.

\section{PENDAHULUAN}

Bahasa adalah alat komunikasi. Sebagai alat komunikasi, pengetahuan mengenai bahasa saja belumlah cukup untuk dapat menciptakan peristiwa komunikasi yang baik dan bermakna. Faktor situasi dan konteks juga 
merupakan faktor penting dalam pemakaian bahasa. Kenyataan inilah yang menyebabkan pragmatik memiliki peranan yang cukup penting dalam kehidupan berbahasa, karena dengan mempelajari dan menguasainya seseorang tidak hanya akan memiliki pengetahuan tentang bahasa, selukbeluk struktur sebuah bahasa, dan cara bahasa (ujaran) itu dipergunakan berdasarkan situasi yang dihadapi pada saat berkomunikasi.

Dalam dunia pendidikan dan pengajaran bahasa, pragmatik dipakai sebagai pendekatan pengajaran atau yang lazim disebut dengan pendekatan komunikatif. Di dalam pengajaran dengan pendekatan komunikatif, bahasa diajarkan seperti pada saat digunakan dalam komunikasi. Hal yang ingin dituju bukanlah pencapaian pengetahuan mengenai tata bahasa atau penguasaan terhadap kosakata, melainkan kemampuan komunikatif atau kemampuan siswa berbahasa untuk tujuan komunikasi, baik itu dengan guru maupun dengan teman dan masyarakat sekitar. Leech (1993:1) menyatakan bahwa pragmatik sesuai dengan fungsi komunikatif karena pragmatik adalah ilmu mengenai bagaimana bahasa itu digunakan dalam komunikasi. Salah satu bagian pragmatik yang paling nyata peranannya dalam komunikasi adalah implikatur percakapan. Jadi konsep implikatur itu dipakai untuk menjelaskan perbedaan yang sering terjadi antara "apa yang diujarkan" dan "apa yang diimplikasikan” (Sumarsono, 2007:84).

Seperti lazimnya kegiatankegiatan sosial lainnya, kegiatan berkomunikasi atau bertutur dapat berlangsung dengan baik apabila semua peserta pertuturan itu terlibat secara aktif di dalam proses bertutur tersebut. Apabila salah satu pihak tidak terlibat dalam kegiatan bertutur, dapat dipastikan pertuturan itu tidak dapat berjalan dengan lancar. Agar proses komunikasi penutur dan petutur dapat berjalan baik, mereka haruslah dapat saling bekerja sama.

Dalam percakapan formal, prinsip kerja sama Grice masih relevan diterapkan. Dalam hal ini, prinsip kerja sama Grice menghendaki penggunaan bahasa yang efektif dan efisien seperti tampak pada maksim-maksim atau prinsip kerja sama tersebut. Dengan kata lain, prinsip kerja sama dibutuhkan untuk lebih mudah menjelaskan hubungan maksud dengan ujaran. 
Berdasarkan kenyataan tersebut, dalam situasi tertentu pada pembelajaran di kelas, semakin taat dengan prinsip-prinsip kerja sama Grice dalam bertutur guru dan siswa, maka cenderung memberikan dampak yang positif, seperti (a) siswa mudah memahami penjelasan guru dan sebaliknya, guru lebih mudah memaparkan sesuatu kepada siswa, (b) bahan atau materi pelajaran lebih cepat dapat diselesaikan atau diajarkan, (c) waktu yang diperlukan lebih efisien. Berdasarkan Kurikulum Tingkat Satuan Pendidikan, prinsip kerja sama masih diperlukan dalam pembelajaran di kelas. Jika dilihat pada silabus, pelaksanaan prinsip kerja sama ini berkaitan dengan standar kompetensi berbicara. Walaupun demikian, kita tidak dapat memfokuskan pada satu kompetensi dasar saja karena setiap materi pelajaran yang diajarkan di kelas pasti dilengkapi dengan percakapan.

Namun, ada kemungkinan prinsip kerja sama Grice sering dilanggar. Hal itu disebabkan oleh bermacam-macam sebab. Misalnya, hasil observasi yang dilakukan di Kelas XI SMAN 1 Kediri menunjukkan bahwa pengetahuan siswa yang masih kurang tentang pelajaran, kebiasaan siswa dan guru berbicara yang panjang lebar dengan menggunakan kalimat mubazir berakibat pada pelanggaran terhadap prinsip kuantitas dan adanya kebiasaan seperti menghindar dari tugas menyebabkan adanya pelanggaran terhadap prinsip relevansi.

Pelaksanaan prinsip kerja sama Grice, baik menaati maupun melanggarnya tentu membawa dampak terhadap pembelajaran di kelas. Dampak yang dimaksud dapat berupa efektif atau tidaknya pembelajaran, menyenangkan atau tidaknya situasi kelas, aktif atau tidaknya siswa, dan berkembang atau tidaknya aktivitas siswa di kelas. Hal itu membuat peneliti tertarik untuk mengkajinya.

Kajian prinsip kerja sama dalam percakapan guru dan siswa di kelas dapat dilakukan dengan melihat percakapan sebagai aktivitas komunikasi verbal dalam interaksi sosial. Sebagai aktivitas komunikasi verbal dalam interaksi sosial, percakapan di kelas dapat disebut wacana, yaitu peristiwa komunikasi yang ditandai oleh penggunaan bahasa antara penutur dan mitra tutur yang bersifat resiprokal bersemuka untuk mencapai tujuan sosial (Richard, 1995:3). Tujuan sosial yang dimaksud 
dalam pandangan tersebut mengacu kepada upaya pelaku tutur untuk mencapai pemahaman bersama dan menjalin hubungan harmonis. Hal itu tampak pada pendapat Searle (1969), Leech (1995), Sperber dan Wilson (1998) (dalam Arifin, 1998:30), dan Dardjowidjojo (2003) yang menyebutkan bahwa percakapan dilakukan untuk menyatakan maksud guna mencapai dan mengandalkan pemahaman bersama. Tujuan sosial yang dimaksud juga mengacu kepada penciptaan hubungan harmonis untuk menjalin kerja sama dan menghindari konflik berdasarkan norma sosial yang berlaku. Dalam pandangan tersebut, tuturan guru dan siswa sebagai unit terkecil percakapan di kelas dipandang sebagai tindak tutur yang mempunyai fungsi dan dampak tertentu.

Selama ini, penelitian mengenai pelaksanaan prinsip kerja sama dalam percakapan guru dan siswa belum pernah dilakukan di Sekolah Menengah Atas (SMA), termasuk di Kelas XI SMAN 1 Kediri. Namun, penelitian dengan masalah sejenis telah banyak dilakukan di berbagai tempat, seperti penelitian yang berjudul Implikatur Percakapan Novel-Novel Agung Panji Tisna oleh I Nyoman Seloka Sudiara
(1999), penelitian Putu Eny Susiyanti tahun 2005 yang berjudul Implikatur Percakapan dalam Skenario Film Ada Apa Dengan Cinta, dan penelitian Made Sri Indriani tahun 2005 yang berjudul Makna Pragmatis dalam Percakapan Novel Menjaring Seribu Mimpi Karya Mila Karmila.

Ketiga penelitian tersebut berbeda dengan penelitian yang penulis laksanakan, baik dari segi objek maupun subjek penelitian. Oleh karena itu, penelitian dengan judul Pelaksanaan Prinsip Kerja Sama dalam Percakapan Guru dan Siswa dan Dampaknya terhadap Pembelajaran Bahasa Indonesia di Kelas XI SMAN 1 Kediri menarik dan perlu untuk dilakukan.

Dengan dilaksanakannya penelitian mengenai pelaksanaan maksim kerja sama ini, diharapkan orang-orang yang setiap hari berkecimpung di dunia pendidikan, terutama guru dan siswanya, lebih menyadari bahwa dalam situasi tertentu dalam pembelajaran di kelas kemampuan berbahasa yang baik sangat penting artinya, yaitu agar tidak terjadi salah penafsiran terhadap maksud yang ingin disampaikan pada saat berkomunikasi. 
Berdasarkan latar belakang di atas, dapat dirumuskan beberapa permasalahan yakni (1) Konteks pembelajaran yang bagaimanakah sebagai tempat relevan pelaksanaan prinsip kerja sama dalam pembelajaran di kelas? (2) Bagaimanakah pelaksanaan prinsip kerja sama yang dilakukan guru? (3) Bagaimanakah pelaksanaan prinsip kerja sama yang dilakukan siswa? (4) Bagaimanakah dampak pelaksanaan prinsip kerja sama yang dilakukan guru dan siswa terhadap pembelajaran Bahasa Indonesia di kelas XI SMAN I Kediri?

\section{METODE PENELITIAN}

Penelitian ini mengkaji pelaksanaan prinsip kerja sama dalam percakapan guru-siswa dan dampaknya terhadap pembelajaran bahasa Indonesia di Kelas XI SMAN 1 Kediri. Kajian tersebut merupakan kajian penggunaan bahasa sebagai fenomena sosial. Karena mengkaji gejala atau fenomena sosial, penelitian ini menggunakan rancangan deskriptif kualitatif. Hal itu sesuai dengan pendapat Margono (2003:36) yang mengatakan bahwa rancangan penelitian dapat diartikan sebagai strategi mengatur latar (setting) agar peneliti memperoleh data yang tepat (valid) sesuai dengan karakteristik variabel dan tujuan penelitian. Rancangan penelitian deskriptifkualitatif adalah rancangan penelitian yang digunakan sebagai prosedur mengidentifikasi dan mendeskripsikan fenomena yang terjadi di lapangan dengan apa adanya, tanpa adanya unsur rekayasa.

Subjek dalam penelitian ini adalah siswa dan guru bahasa Indonesia kelas XI SMAN I Kediri. Objek penelitian ini secara umum adalah pelaksanaan prinsip kerja sama dalam percakapan guru-siswa dan dampaknya terhadap pembelajaran bahasa Indonesia di Kelas XI SMAN 1 Kediri. Secara khusus, adalah (1) konteks pembelajaran sebagai tempat pelaksanaan prinsip kerja sama dalam pembelajaran di kelas, (2) pelaksanaan prinsip kerja sama yang dilakukan guru, (3) pelaksanaan prinsip kerja sama yang dilakukan siswa, dan (4) dampak pelaksanaan prinsip kerja sama yang dilakukan guru dan siswa terhadap pembelajaran Bahasa Indonesia di kelas XI SMAN I Kediri.

Penelitian ini menggunakan tiga metode pengumpulan data, yaitu (1) metode perekaman, (2) metode observasi, dan (3) metode wawancara. 
Untuk mendeskripsikan penggunaan pelaksanaan prinsip kerja sama dalam percakapan guru-siswa dan dampaknya terhadap pembelajaran bahasa Indonesia di Kelas XI SMAN 1 Kediri, diperlukan data berupa penggunaan tuturan siswa dalam percakapan siswa-guru dan percakapan guru-siswa saat KBM berlangsung. Untuk mendapatkan data tersebut, peneliti menggunakan metode perekaman. Melalui metode perekaman ini, peneliti berusaha semaksimal mungkin mendapatkan rekaman tuturan yang sebanyak-banyaknya dari proses interaksi verbal dalam KBM bidang studi bahasa Indonesia. Metode observasi digunakan untuk memperoleh data catatan hasil observasi atau catatan lapangan tentang pelaksanaan pembelajaran dan perkembangan situasi yang terjadi terkait dengan pelaksanaan prinsip kerja sama dalam percakapan guru-siswa dan dampaknya terhadap pembelajaran bahasa Indonesia di Kelas XI SMAN 1 Kediri. Metode wawancara digunakan untuk memperoleh data yang tidak terekam oleh tape recorder dan tidak teramati atau tidak tercatat saat observasi. Dalam hal ini, teknik wawancara sangat diperlukan untuk memperoleh data, seperti alasan guru dan siswa melaksanakan prinsip kerja sama, alasan guru dan siswa melanggar prinsip kerja sama, dan hal-hal lain yang terkait dengan masalah penelitian saat KBM berlangsung di kelas. Metode wawancara yang dilakukan lebih banyak berupa pengajuan pertanyaan konfirmasi secara tidak terstruktur. Analisis data dalam penelitian ini menggunakan prosedur analisis data kualitatif yang mencakup empat tahap, yaitu (1) pengumpulan data, (2) reduksi data, (3) penyajian data, dan (4) verifikasi dan penarikan simpulan.

\section{HASIL PENELITIAN DAN PEMBAHASAN}

Konteks Pembelajaran sebagai Tempat Pelaksanaan Prinsip Kerja

\section{Sama di Kelas}

Data penelitian ini menunjukkan bahwa tempat pelaksanaan prinsip kerja sama dominan pada situasi formal, situasi tidak terlalu formal, dan pada situasi informal, saat Secara jelas hal itu tampak pada uraian di bawah ini.

Pertama, situasi formal, saat guru menjelaskan materi pelajaran dapat dikatakan sebagai konteks pembelajaran yang menjadi tempat dominan pelaksanaan prinsip kerja sama di kelas. Prinsip kerja sama bisa terjadi dalam 
konteks tersebut, karena guru serius menjelaskan materi dengan menggunakan bahasa yang lugas, jelas, dan mudah dipahami siswa. Sementara itu, siswa juga dituntut untuk menanggapi, menjelaskan, atau menjawab pertanyaan guru dengan menggunakan bahasa yang lugas, jelas, dan mudah dipahami siswa. Prinsip kerja sama yang dilaksanakan guru atau pun siswa dapat berupa maksim kuantitas, maksim kualitas, maksim relevansi, dan maksim cara.

Kedua, prinsip kerja sama juga terjadi pada situasi tidak terlalu formal, misalnya saat guru menegaskan kembali materi pelajaran. Prinsip kerja sama bisa terjadi dalam konteks tersebut, karena guru serius menjelaskan materi dengan menggunakan bahasa yang lugas, jelas, dan mudah dipahami siswa. Namun demikian, prinsip kerja sama terutama maksim kuantitas sering dilanggar. Hal itu bisa terjadi karena adanya upaya guru memotivasi, memberikan nasehat, meminta perhatian, atau menegur siswa dengan tuturan-tuturan panjang yang cenderung santun.

Ketiga, pada situasi informal, saat guru dalam menuntun siswa secara individu atau membicarakan masalah pribadi dengan menjalin hubungan akrab masalah pribadi dengan siswa, prinsip kerja sama terutama maksim kuantitas dan juga maksim kualitas cenderung dilanggar.

\section{Pelaksanaan Prinsip Kerja Sama yang Dilakukan Guru}

Data penelitian ini menunjukkan bahwa dalam percakapan di kelas, guru mematuhi semua prinsip kerja sama, baik maksim kuantitas, kualitas, relevansi, maupun cara. Tiap tindak tutur dapat mematuhi lebih daripada satu maksim. Dalam percakapan di kelas, tindak tutur guru terhadap siswa mematuhi maksim kuantitas. Keberadaan tindak tutur yang demikian itu, cenderung mengantarkan siswa untuk segera memahami materi pelajaran karena informasi yang diberikan cukup jelas. Dengan kata lain, tindak tutur guru mematuhi maksim kuantitas menunjukkan adanya upaya untuk menyampaikan informasi seinformatif mungkin. Karena itu, tindak tutur tersebut cenderung menunjukkan pencapaian pemahaman bersama sesuai dengan tujuan yang hendak dicapai dalam pembelajaran.

Selain mematuhi maksim kuantitas, tindak tutur guru juga menggunakan maksim kualitas. Tindak tutur tersebut dapat berfungsi atau digunakan untuk 
membenarkan hal yang dituturkan sesuai dengan kenyataan yang ada di kelas. Keberadaan penggunaan maksim yang demikian itu, menunjukkan adanya suatu tindak tutur yang disampaikan oleh guru harus disertai dengan bukti yang sebenarnya.

Hasil penelitian ini juga menunjukkan bahwa dalam percakapan di kelas, tindak tutur guru yang mematuhi maksim relevansi. Tindak tutur tersebut menunjukkan adanya upaya memberikan kontribusi yang relevan tentang sesuatu yang dipertuturkan. Dengan demikian, percakapan yang terjadi antara guru dan siswa memungkinkan terjadinya suatu kerja sama yang diharapkan.

Dalam percakapan di kelas, guru juga harus mengungkapkan pikirannya menggunakan tuturan secara jelas dan runtut. Keruntutan tuturan tersebut tampak pada implikasi atau maksud yang diacunya. Tindak tutur guru tersebut menunjukkan adanya pelaksanaan prinsip kerja sama yaitu mematuhi maksim cara.

\section{Pelaksanaan Prinsip Kerja Sama yang Dilakukan Siswa}

Sama halnya dengan pelaksanaan prinsip kerja sama yang dilakukan guru, data penelitian ini menunjukkan bahwa pelaksanaan prinsip kerja sama yang dilakukan siswa dalam percakapan di kelas dapat berupa tindak tutur yang mematuhi maksim kuantitas, kualitas, relevansi, dan cara. Tindak tutur yang dinyatakan siswa dengan beberapa tuturan dalam percakapan tersebut dapat mematuhi lebih dari satu maksim demi tercapainya tujuan pembelajaran. Tindak tutur siswa yang demikian itu cenderung mencapai pemahaman bersama. Kecenderungan tersebut terkait dengan upaya guru dan siswa mencapai tujuan pembelajaran.

Tiap tuturan siswa dapat mematuhi lebih dari satu maksim. Dalam percakapan siswa terhadap guru, tindak tutur siswa yang mematuhi maksim kuantitas digunakan siswa untuk menanggapi tindak tutur guru dengan memberikan informasi yang diperlukan saja. Tindak tutur tersebut cenderung menunjukkan terciptanya hubungan harmonis dan pencapaian pemahaman bersama. Dikatakan demikian, karena tanpa harus ditambah dengan kata-kata dan informasi lain, tuturan tersebut sudah dapat dipahami dengan jelas oleh mitra tuturnya. Karena itu, tindak tutur tersebut menaati maksim kuantitas dalam menyampaikan suatu informasi. 
Dalam percakapan di kelas, bukan hanya guru yang menggunakan tindak tutur yang menyatakan sesuatu sesuai dengan situasi sebenarnya pada saat pembelajaran di kelas, namun siswa juga melakukan hal yang sama. Keberadaan tindak tutur seperti itu dalam percakapan siswa terhadap guru menunjukkan siswa melaksanakan maksim kualitas.

Dalam bertutur, antara seorang siswa dan guru atau antara siswa dan siswa hendaknya memberikan kontribusi yang relevan tentang sesuatu yang dipertuturkan tersebut. Percakapan yang terjadi antara siswa dan siswa hendaknya memungkinkan terjadinya suatu kerja sama yang diharapkan. Terkait dengan hal itu, hasil penelitian yang dilakukan menunjukkan bahwa tuturan siswa yang menyatakan adanya kontribusi relevan terhadap lawan bicaranya.

Tindak tutur juga disampaikan siswa dari hal awal yang harus dilakukan sampai dengan hal terakhir. Tindak tutur tersebut dinyatakan dengan tuturan yang runtut, tidak acak-acakan. Tindak tutur itu sangat jelas mengacu pada hal-hal inti dan tidak banyak disertai dengan penjelasan langkah tambahan. Dengan demikian akan tercapai kesepakatan bersama yang selanjutnya mencapai pemahaman bersama.

\section{Dampak Pelaksanaan Prinsip Kerja} Sama terhadap Pembelajaran Bahasa Indonesia

Berdasarkan data yang diperoleh di lapangan, hasil penelitian ini menunjukkan adanya dampak pelaksanaan prinsip kerja sama terhadap pembelajaran Bahasa Indonesia di kelas. Dampak pelaksanaan prinsip kerja sama terhadap pembelajaran Bahasa Indonesia yaitu (1) situasi pembelajaran di kelas menjadi kondusif, (2) keaktifan siswa menjadi berkembang, pembelajaran di kelas berlangsung dengan baik, dan (4) tujuan pembelajaran dapat tercapai secara efektif. Hal itu menunjukkan bahwa pelaksanaan prinsip kerja sama berdampak positif terhadap pembelajaran. Dalam hal ini, pelaksanaan prinsip kerja sama menunjukkan bahwa siswa terkesan baik, situasi menjadi tenang, pembelajaran lancar, tujuan pembelajaran tercapai.

\section{PENUTUP}

\section{Simpulan}

Berdasarkan hasil penelitian dan pembahasan di atas, dapat disampaikan simpulan-simpulan sebagai berikut. 
1. Konteks pembelajaran sebagai tempat pelaksanaan prinsip kerja sama di kelas, dominan terjadi pada konteks situasi formal, pada saat guru menjelaskan materi pelajaran. Pelaksanaan prinsip kerja sama terjadi pula pada situasi tidak terlalu formal, tampak pada saat adanya tindak tutur guru dan siswa yang menegaskan kembali teori yang telah dijelaskan dengan menambah argumen pendukung. Pada situasi informal, tampak pada saat guru terlibat masalah pribadi dengan siswa, tampak adanya pelaksanaan prinsip kerja sama, tetapi dalam hal ini prinsip kerja sama tersebut cenderung dilanggar.

2. Pelaksanaan prinsip kerja sama yang dilakukan guru ditandai oleh tindak tutur yang dinyatakan dengan tuturan yang mematuhi maksim kuantitas, maksim kualitas, maksim relevansi, dan maksim cara.

3. Pelaksanaan prinsip kerja sama yang dilakukan siswa ditandai oleh tindak tutur yang dinyatakan dengan tuturan yang mematuhi maksim kuantitas, maksim kualitas, maksim relevansi, dan maksim cara.
4. Dampak yang ditimbulkan dalam pelaksanaan prinsip kerja sama terhadap pembelajaran Bahasa Indonesia adalah situasi pembelajaran di kelas yang menjadi nyaman dan kondusif, aktivitas siswa berkembang, pembelajaran berlagsung dengan baik, tidak terhambat, dan tujuan pembelajaran dapat dicapai secara efektif.

\section{Saran}

Hasil penelitian ini dapat dijadikan masukan oleh pembaca terutama guru dan siswa guna memperluas wawasan tentang prinsip penggunaan bahasa. Dengan wawasan tersebut, diharapkan pembaca terutama guru dan siswa semakin menyadari bahwa dalam penggunaan bahasa (tuturan), prinsip kerja sama perlu diperhatikan sehingga tuturan menjadi lebih efektif dan efisien. Dengan demikian, komunikasi dapat terjalin dengan baik, saling bekerja sama, dan mencapai sasaran sesuai dengan yang diharapkan.

\section{DAFTAR PUSTAKA}

Arifin. (2008). Penggunaan tindak tutur siswa di kelas. Disertasi (tidak dipublikasikan). Malang : Universitas Negeri Malang. 
Dardjowidjojo, Soenjono. (2003). Psikolinguistik pengantar pemahaman bahasa manusia. Jakarta : Yayasan Obor Indonesia.

Indriani, Sri. (2005). Makna pragmatis dalam percakapan novel menjaring seribu mimpi karya mila karmila. Karya Ilmiah (tidak dipublikasikan). Jurusan Pendidikan Bahasa dan Sastra Indonesia. Singaraja : IKIP Negeri Singaraja.

Leech. G. (1993). Prinsip-prinsip pragmatik. Terjemahan M.D.D.Oka.1993. Jakarta: Universitas Indonesia.

Margono. S. (2003). Metodologi penelitian pendidikan. Jakarta: PT Bineka Cipta.
Sudiara, I Nyoman Seloka. (1999). Implikatur percakapan novel-novel agung panji tisna. Tesis (tidak dipublikasikan). Malang: IKIP N Malang.

Sumarsono. (2007). Pragmatik. (Buku Ajar). Singaraja: Undiksha.

Susiyanti, Eny Putu. (2005). Implikatur percakapan dalam skenario "ada apa dengan cinta". Skripsi (tidak dipublikasikan). Singaraja: Undiksha.

Wijana, I Dewa Putu. (1996). Dasardasar pragmatik. Yogyakarta: Andy.

Yule, George. (2006). Pragmatik. Yogyakarta: Pustaka Pelajar. 